\title{
Student-adult mentoring relationships: experiences from a Scottish school-based programme
}

\author{
Peter Mtika, Frances Payne
}

\section{University of Aberdeen}

Background: This article reports on a mentoring programme which was implemented in selected Scottish secondary schools with the view to supporting students with school work, transition to further education/higher education, careers, and interpersonal skills. Mentoring students can enhance their academic, social, career and other outcomes. Mentoring relationships, when properly implemented, also yield positive results for mentors.

Purpose: This paper is an investigation into conditions under which a schoolbased mentoring programme was implemented in selected Scottish schools. In so doing, we hope to contribute to an evolving framework for designing and implementing successful school-based mentoring.

Sample: The sample for this study included 10 students aged between 16 and 17 years old and 11 mentors with whom they were paired. The mentors were drawn from various industries, mainly in the science, health and the education sectors.

Design and method: Methodologically, this study was qualitative in nature. Methods of data collection involved focus group discussion and semi-structured interviews.

Results: The findings show mentee and mentor preparation, clarity of expectations, mentee-mentor matching, mentee motivation, appropriateness of meeting spaces and power relations, modes of communication including the use of social media, and the role of schools as essential conditions which influenced the quality of mentoring relationships.

Conclusion: The findings suggest that mentoring programmes involving students in school and 'external' adult mentors need to consider a range of factors to achieve success when designing and implementing mentoring. This paper raises important issues for example, communication using social media, which have 
implications for practice in business sector and school partnerships involved in school-based mentoring.

Keywords: mentoring relationships, school-based mentoring, Scotland

\section{Introduction}

Mentoring has become a centrepiece in many schools and business organisations for enhancing academic, social and career outcomes for young people and early career professionals (Ahn 2010; Colley 2003; Hickman and Garvey 2006; Leidenfrost et al. 2011; Lunsford 2012; MacCallum and Beltman 2003; McDowall-Long 2004; Philip 2003; Reid 2002; Sims et al. 2000). It has been recorded as one of the most used approaches for supporting personal and professional development (Colvin and Ashman 2010; Hughes, Boyd, and Dykstra 2010; Kolar and McBride 2011; McDowall-Long 2004).

Potential benefits of mentoring have been overwhelmingly reported and these include increased self-esteem, improved problem-solving skills, better decision-making and better general life skills (MacCallum, Beltman, and Palmer 2005). Hickman and Garvey (2006) found that students who had been mentored were three times more likely to enrol in further education/higher education $(\mathrm{FE} / \mathrm{HE})$ than a comparison group. Other benefits for mentored students include well-developed employability and interpersonal skills (Kolar and McBride 2011). These wide ranging benefits have inevitably contributed to a positive stance by governments and the private sector towards mentoring initiatives. However, measuring the impact of mentoring is said to be complex as there are usually cases of misplaced attribution (MacCallum, Beltman, and Palmer 2005). This is particularly the case because mentoring can mean different things to different individuals and yet the impacts of such relationships are usually conflated. Also, components of mentoring relationships and characteristics of mentees and 
mentors vary greatly across programmes (Larose et al. 2009). It is therefore important that when evaluating mentoring relationships, researchers clearly describe what they mean by mentoring, the context in which mentoring was implemented, and consider conceptual design principles of mentoring. However, an undisputable consensus is that all mentoring strives '.. for positive growth, development and self-actualisation' (Roberts 2000, 162).

The argument in favour of adults from business and industry supporting school students through mentoring programmes is partly attributable to the observation that most secondary students graduate from school ill-prepared for FE/HE or the world of work (Hall 2003; Moore et al. 2010). This is due to the fact that, in many educational systems, a secondary teacher's time is largely spent teaching specific discrete academic subjects, rather than supporting the development of the whole person. Teachers also present workload pressures as a further impediment to their attending to all aspects of students' welfare in school. However, some of this apparent neglect is moderated by the existence of a pastoral care system in schools in the United Kingdom (UK) and other countries around the world, whereby some subject teachers opt to include pastoral care in their workload. Mentors who support students are normally expected to be those 'significant others' who can be a source of motivation for young people. This is why mentor-mentee pairing needs to be cautiously navigated for the potential benefits of mentoring to be realised. Furthermore, for a successful mentoring relationship there has to be a sense of equality between the mentor and mentee.

According to Reid (2002), a mentor creates a shared space in which mentees can consider their circumstances and develop goals. Evertson and Smithey (2001) found that trained mentors demonstrated better awareness of mentees' needs. Qualities which effective mentors possess include: approachability, tact and empathy, trustworthiness, 
listening skills, self-awareness, an interest in developing others, and good relationship skills (Clutterbuck 2001; Reid 2002). Mentees also have a significant part to play in the creation of mentoring relationships. Larose et al. $(2009,109)$ suggested that 'the motivations, attitudes, values, goals, and needs of mentees at the onset of the mentoring relationship may foster...involvement in the relationship and the potential benefits for their development'.

In this paper, we focus on the school-based mentoring relationships of some secondary students in Scotland who had expressed an interest in being mentored as part of a larger project intended to support young people's transition from school to the world of work, further education or higher education. By school-based mentoring relationships, we mean 'a sustained relationship between a young person and a volunteer adult in which the adult provides the young person with different types of academic, social, career and interpersonal support' (Larose et al. 2011, 112). We examine the conditions under which a school-based mentoring programme was implemented. In so doing, we hope to contribute to an evolving framework for designing school-based mentoring programmes.

\section{Research context}

Recently, there has been a proliferation of studies which examine mentoring of young people from diverse backgrounds in the UK (Colley 2003; Philip 2003; Sandford, Armour and Stanton 2010; Sims, Jamison, Golden and Lines 2000). Many 'claims [have] also been made on the impact of mentoring but there is as yet little evidence to confirm them' (Hall 2003, 15). As further mentoring programmes are being implemented in the UK, the literature recommends that researchers should embark on 
studies which examine the mentoring relationships within these programmes as well as their outcomes (Colley 2003; Reid 2002).

The political will for mentoring became significantly more evident following the election of a Labour Government in 1997 which allocated an increased funding to the national mentoring network, and provided national leadership to various mentoring initiatives (Colley 2003). In Scotland there are well established mentoring initiatives which offer one to one mentoring for young people. Some involve students and teachers in-school (Education Scotland 2013), others involve schools and business, for example, Scottish Business in the Community (2013), and others - Day1 (2013) that mainly focus on supporting young people from difficult or disadvantaged backgrounds.

With the implementation of the Curriculum for Excellence (CfE) (Scottish Executive 2004), the national curriculum for 3-18 year olds, a number of policy documents were issued by the Scottish Government that advocated the importance of adult support and advice. 'Building the Curriculum 3 - A Framework for Learning and Teaching' (2008) states:

All children and young people should have frequent and regular opportunities to discuss their learning with an adult who knows them well and can act as a mentor, helping them to set appropriate goals for the next stages in learning (Scottish Government 2008, 17).

In the Senior Phase of the curriculum (15-18 years) this has included a commitment to supporting students' transition from school to FE/HE or employment (Scottish Executive 2006; Scottish Government 2010). The document '16+ Learning Choices, Policy and Practice Framework' (Scottish Government 2010) highlights the importance of a multi-agency approach whereby: 
Every young person who is eligible to leave compulsory education and is making a transition to further learning, training or employment within the Senior Phase should receive an offer of post-16 learning. Effective transition planning will ensure that the offer is in place in advance of their planned date for leaving school or other episode of learning... All eligible young people will get high quality, impartial careers information, advice and guidance from SDS [Skills Development Scotland] to help them decide on and take up the post-16 learning choice that is right for them. Additionally, they will get the support they need to help them sustain their learning choice; with more intensive, on-going support for particularly vulnerable young people (Scottish Government 2010, 8).

The 2010 document does not explicitly mention mentoring pupils during transition from school to work. However, it sits within 'Curriculum for Excellence: Building the Curriculum 3 - A Framework for Learning and Teaching' (Scottish Government 2008) where there is an expectation that all stakeholders involved in the Senior Phase who support young people in a range of formal learning and less formal learning environments work together in local partnerships to deliver the strategy. This includes understanding the world of work, career advice, and support to achieve the right choices. Hence there is an expectation that mentoring can play an important role in supporting young people to make decisions about their future learning options beyond compulsory schooling.

\section{The school-based mentoring programme}

The programme reported here was influenced by the concept of socio-motivational mentoring in which structure, involvement, and autonomy support form essential elements for raising young people's motivation and achievement (Larose and Tarabulsy 
2005). Socio-motivational mentoring entails setting out clear objectives and activities through which mentors and mentees can establish a stable and mutual involvement. The nature of the relationship between mentors and mentees is intended to be non-directive but supportive to ensure a mentee's gradual move towards autonomy (Larose and Tarabulsy 2005). Mok (2010) noted that in social-motivational mentoring, the relationship between a mentor and mentee raises the mentee's sense of independence and confidence. Furthermore, this mentoring orientation offers agentive 'space' to mentees to develop skills, knowledge and appropriate attitudes (Britner et al. 2006).

The mentoring programme was one element in the second year of a larger two year project (2009-2011) which aimed to increase the number of students aspiring to enrol in FE and/or HE, as well as the numbers interested and engaging in health or science, technology, engineering and mathematics (STEM) careers. This was to be achieved through providing a range of activities (see, Authors, [2011]) for students both outwith and in school time with the main aim of providing opportunities for confidence building and flexible contextual learning which would better prepare young people for post-compulsory schooling and the world of work.

....Children and young people should have opportunities to: build knowledge and understanding of the workplace, what employers may expect of them and what they should expect from employment... and so enable them to develop the skills, confidence and abilities to become the employees, employers and entrepreneurs of the future (Scottish Government 2008, 16).

This project was implemented in a local authority in which the main challenge facing young people on leaving school was the distances across a wide geographical area between predominantly rural communities and compounded by a low base of manufacturing industries in the region and limited opportunities for employment. 
Equally there was a perceived lack of students' awareness of STEM opportunities and also a trend for school leavers to go directly into employment rather than aspire to FE or HE. The project's objectives were: to provide students with guidance on careers, academic work, and FE/HE; and to increase students' confidence in their own abilities.

The main project partners consisted of educational institutions (secondary schools, a local FE college and university, the local authority), the government's regional economic and community development agency, and an international health care company. The company which has a long history of encouraging its workforce to be active in a range of initiatives in the local community as well as supporting young people, contributed to the local community by funding and supporting activities for secondary students, for example, employability workshops, job shadowing and teambuilding activities at outdoor centres.

Students who took part in the main project volunteered to do so and were drawn from six secondary schools in diverse urban, semi-rural and rural geographical locations. In the first year of the project they were in year S4 (15-16 years) and in their feedback to the organisers at the end of first year some students requested mentor support, principally for career advice. In response to this the partners set up a mentoring programme which commenced in year 2 for the students, now in S5 (16-17 years).

With the Scottish Government's (2010) 16+ Learning Choice policy being implemented and guidance teachers already supporting all students in pastoral care, career advice, and college/university applications, the mentoring programme was viewed as practical and complementary to the work of such teachers. Specifically, students on this programme had additional access to external mentors other than their guidance teachers and these mentors provided a range of support such as informing 
students of a range of pathways to jobs/careers, FE/HE, and arranging job contacts as well as visits to health-related industries.

Of the 31 students in the programme, 21 were female and 10 were male. All the students in year S5 had responded affirmatively when invited to have a mentor. Except for one, all students considered English as their first language. There were 27 mentors in the programme and each mentor had at least one student to support. Mentors were either already registered, trained and had undergone Disclosure Scotland ${ }^{1}$ (DS) checks as STEM ambassadors in Scotland (STEMScotland 2013) which is part of the wider UK national STEM ambassador programme. They were already working in various capacities as an inspiring role model for young people, and shared a commitment to improving the academic, career and future life opportunities for the young people they supported. They had all responded positively to an email request from the project organisers to confirm an interest in acting as a mentor. Others who acted as mentors were mainly project steering group members who worked principally in educational settings.

Specifically, mentors were professionals working mainly in the STEM, health, business and education sector and included staff from the company which provided funding to the programme, employees of the National Health Service (NHS) and partner organisations on the project steering committee. Career roles included an aerospace engineer, pharmacist, and a science lecturer, etc. Before the eight month programme began in September 2010 mentors first completed a questionnaire about their background including their hobbies and students provided information about career

1 Disclosure Scotland is an agency of the Scottish Government which carries out a criminal record check and checks for other relevant information to ensure the person is suitable to work with children and vulnerable adults. 
interests and subject interests. The coordinator of the mentoring programme in association with others on the project steering committee used this information to match students with mentors based on similarity in career interests.

A half-day induction for mentors was organised by the project committee and led by an experienced mentor trainer to familiarise them with the programme. A separate session was held for the students. At the launch of the programme, a mentormentee 'mingle' session was organised for mentees and mentors to meet for the first time to which parents were invited. Most of the mentors on the programme were able to meet mentees' parents as well during this event. The importance of parental involvement in one way or the other has been highlighted in other mentoring programmes (MacCallum, Beltman, and Palmer 2005). Mentors and their mentees were able to initiate preliminary conversations on how they hoped their paired relationship would evolve over the programme's duration.

Although general guidance was given to mentors and mentees there were no formal guidelines on the number of times mentees and mentors were expected to meet during the next eight months, what they were expected to do during their meetings, and how the mentoring time would be spent. It was left to mentors and mentees to flexibly decide the focus of meetings depending on the mentees' needs. However, the general expectations were that mentors would explore with the mentees their career interests, clarify academic interests, help with school work in science, broaden mentees' understanding of the world of work, and help with general life skills. Even though mentoring was school-based, the venues for meetings were not prescribed. 


\section{The study}

\section{Methodology}

This study was conducted as part of an evaluation of the broader business/education two-year partnership project. Student mentoring was one strand of the broader project. The authors, who played no role in the design of the mentoring programme, were already acting as independent evaluators of the project. As part of the data collection for the overall project in year 2, we sought to determine how effective the mentoring strand had been. To do that, we examined a range of aspects of the mentoring relationships, including the dynamics and the benefits for students. Our research questions in the study were:

(a) How was a school-based mentoring programme involving six schools implemented;

(b) What lessons can be learnt from the implementation of the programme?

Qualitative methodology was adopted in the study. Silverman (2005) noted that qualitative research tends to work with a relatively small number of cases and 'sacrifices scope for detail' (Silverman 2005, 9). By adopting qualitative methodology, we hoped to understand 'how social experiences are created and given meaning' (Denzin and Lincoln 1994, 10). From this, we could potentially develop perspectives of school-based mentoring relationships from mentors and mentees. However, the researchers had no say in selecting students who were purposively selected (Merriam 2009) by the steering committee from the students in the six schools in the main project. Mentors were self-selected and therefore we focus in this study on the general relationships without necessarily exploring specific dyads. 


\section{Study participants and data collection}

\section{Mentors}

Eleven mentors participated in the study. Seven mentors ( 5 female and 2 male)

volunteered to participate in three separate focus group discussions comprising 2 females; 2 females and 1 male; and 1 female and 1 male respectively which were conducted with two researchers present. A further four individual interviews (one via telephone) were conducted with the remaining mentors, who were not available at the time of the focus group discussions. All interviews were audio recorded and later transcribed as were those with mentees. Additional information about some of the participating mentors and details about how and where they engaged with their mentees are presented in Table 1 below. The level of detail included is reflected in whether the mentor or mentee provided the information in the interview and/or discussion.

Table 1: Information about participating mentors $(n=11)$

\begin{tabular}{|c|c|c|c|}
\hline Gender & $\begin{array}{l}\text { Mentor } \\
\text { career/work role }\end{array}$ & $\begin{array}{l}\text { Mode of communication } \\
\text { with mentee between } \\
\text { face to face meetings }\end{array}$ & Venue for meeting \\
\hline Male & $\begin{array}{l}\text { Electronic } \\
\text { engineer }\end{array}$ & $\begin{array}{l}\text { Email mostly. Boy not } \\
\text { very technological, no } \\
\text { mobile. Both parties } \\
\text { initiated contact equally. }\end{array}$ & School \\
\hline Male & $\begin{array}{l}\text { Maintenance team } \\
\text { leader }\end{array}$ & $\begin{array}{l}\text { Text and email. } \\
\text { Both initiated contact, } \\
\text { boy initiated } 60-70 \% \text {. }\end{array}$ & $\begin{array}{l}\text { School common room (x1) } \\
\text { but interruptions } \\
\text { Coffee shops (several times) }\end{array}$ \\
\hline Female & Quality Engineer & $\begin{array}{l}\text { 'Do lot of texting and } \\
\text { emailing'. }\end{array}$ & School \\
\hline Male & $\begin{array}{l}\text { Aerospace } \\
\text { engineer }\end{array}$ & $\begin{array}{l}\text { No direct contact, all via } \\
\text { teacher. }\end{array}$ & $\begin{array}{l}\text { School - corner of } \\
\text { classroom, difficult for good } \\
\text { conversation }\end{array}$ \\
\hline Male & Software designer & $\begin{array}{l}\text { Email and Skype. } \\
\text { Mentor not given } \\
\text { student's phone number. }\end{array}$ & $\begin{array}{l}\text { School (x1) } \\
\text { Skype (x2) }\end{array}$ \\
\hline Female & Pharmacist & $\begin{array}{l}\text { Swapped email addresses } \\
\text { but girl preferred to text. } \\
\text { Facebook. }\end{array}$ & School \\
\hline
\end{tabular}




\begin{tabular}{|c|c|c|c|}
\hline Female & $\begin{array}{l}\text { STEM } \\
\text { Ambassador } \\
\text { programme }\end{array}$ & Email. & $\begin{array}{l}\text { School - met in mentee's } \\
\text { free study period }\end{array}$ \\
\hline Female & $\begin{array}{l}\text { Subject network } \\
\text { leader for science }\end{array}$ & $\begin{array}{l}\text { Mentor initiated contact } \\
\text { and also informed } \\
\text { guidance teacher when } \\
\text { due to meet mentee. }\end{array}$ & School \\
\hline Female & $\begin{array}{l}\text { Community } \\
\text { relations }\end{array}$ & $\begin{array}{l}\text { Mentor initiated contact } \\
\text { via phone. }\end{array}$ & School \\
\hline Female & $\begin{array}{l}\text { LA Education } \\
\text { Department }\end{array}$ & $\begin{array}{l}\text { Facebook and mobile } \\
\text { phone - texting. }\end{array}$ & Coffee shop \\
\hline Female & $\begin{array}{l}\text { LA Education } \\
\text { Department }\end{array}$ & $\begin{array}{l}\text { Mentor initiated contact } \\
\text { most of time via text or } \\
\text { phone calls. }\end{array}$ & $\begin{array}{l}\text { Kept guidance teacher } \\
\text { informed of meeting dates, } \\
\text { not needed at later stage }\end{array}$ \\
\hline
\end{tabular}

\section{Mentees}

The ten ( 7 female and 3 male) participating students were interviewed in two focus groups, one comprised 4 female and 1 male students, and the other group comprised 3 female and 2 male students. Almost all of the students were already interested in a STEM career and had stayed on at school after compulsory education ended at sixteen years. Additional information about the participating students is contained in Table 2 below.

Table 2: Information about participating students $(n=10)$

\begin{tabular}{|c|c|c|c|}
\hline Gender & $\begin{array}{l}\text { Plans for first year } \\
\text { after leaving } \\
\text { secondary school }\end{array}$ & Favourite subjects & Career aspiration \\
\hline Male & University & Physics and chemistry & Engineering \\
\hline Male & University & Chemistry, biology & $\begin{array}{l}\text { Marine } \\
\text { biology/conservationist }\end{array}$ \\
\hline Male & University & $\begin{array}{l}\text { English, chemistry, } \\
\text { history, geography }\end{array}$ & Law \\
\hline Female & Gap year & English & $\begin{array}{l}\text { Navy engineer/teaching } \\
\text { English abroad/geologist }\end{array}$ \\
\hline Female & University/get a job & Business management & Business course \\
\hline Female & University & Chemistry, biology & Biochemistry \\
\hline Female & University & Chemistry, biology & Biochemistry \\
\hline Female & $\begin{array}{l}\text { Get a job/further } \\
\text { education college }\end{array}$ & Chemistry & Undecided \\
\hline
\end{tabular}




\begin{tabular}{llll} 
Female & $\begin{array}{l}\text { Get a job/go into the } \\
\text { army, navy or other } \\
\text { uniformed services }\end{array}$ & Biology, geography & Forensic science \\
Female & $\begin{array}{l}\text { Gap year/university } \\
\text { Physics, maths, } \\
\text { modern languages }\end{array}$ & Engineering \\
\hline
\end{tabular}

Consent had been given by all student and adult participants prior to the interviews after receiving an information sheet, worded appropriately to the age group, detailing who the researchers were, why we were involved, the purposes of the discussions/interviews, what taking part involved and reassurance of anonymity and confidentiality. Importantly, at the time of the interviews parental consent was not requested as students had attained their $16^{\text {th }}$ birthday and according to Scots law are treated as adults and were able to give their own consent. Parents were aware interviews were taking place and had given consent in the previous round of interviews a year earlier.

\section{Data analysis}

Data analysis was underpinned by open coding (Strauss and Corbin 1990) and thematic analysis. Data were transcribed, after which each researcher familiarised themselves with the group discussion/individual interview transcripts. As is the case with the analysis of interview data, a systematic iterative process was utilised to scrutinise transcripts for semantic units from which to develop related themes (Langdridge 2004). Codes were assigned to sentences, or phrases in the transcripts and systematically moved about into categories which related to the research question. The categories developed by each researcher were then compared to ensure inter-rater reliability (Armstrong et al. 1997). 
The findings reported here are not generalisable because of the small sample used in a qualitative study (Miles and Huberman 1994). However; these findings may be transferable to other similar settings (Bartlett and Burton 2007). Also, as is often the case with small focus group interview-based data, we do not provide numbers of participants as not all of them discussed each and every question, but rather our findings reflect common views expressed by participants. These findings provide insights into mentoring relationships between professional adults and a small number of students in one area of Scotland. When presenting our findings, pseudonyms are used for students' quotes while numbers are used for mentors to preserve anonymity (Lankshear and Knobel 2004).Selected salient quotes representing thought processes from mentors and mentees interviewed are used to present and illustrate findings.

\section{Findings}

Our findings on the benefits of mentoring are unsurprising and support those of large scale studies in that: 'Mentoring can make a useful contribution to the education and development of young people' (Sims 2002, 5).The summarised benefits of mentoring from this programme included help with career advice, knowledge about university application, organisational skills and academic support, reaffirming the global stance on mentoring. However the main findings in this paper focus on the prevailing conditions in the mentoring implementation process.

As our data show (Table 2) on the whole the students were interested in their education and future life prospects. 


\section{Mentee and mentor preparedness}

With regards to the nature and contents of the induction on the mentoring programme, mentors felt that while the half-day induction for mentors had been helpful it was more geared towards training mentors of early career adults and not secondary students.

I think we needed more emphasis on the young people because the way [the trainer] described it is that the relationship would be led by the young person, but for some of them I don't think they were motivated enough for that. (Mentor 7)

As such, several mentors felt that more time could have been given to preparing students to understand what mentoring involved.

...we would have prepared differently if we were doing it again, probably do some mentor training with the young people so that they knew what a mentor was.... (Mentor 8)

The finding that mentors generally agreed that the induction they had received was not fully aligned with the mentoring of young people suggests that more needed to have been done to appropriately tailor the mentor induction. As suggested elsewhere (see, e.g., Evertson and Smithey, [2001]), training for mentors is intended to provide them with a better awareness of mentees' needs.

\section{Clarity of expectations}

Despite participating in the induction some of the students appeared to be less certain about what being mentored involved, as illustrated by the following comments:

I thought it would be kind of like a therapist, I didn't really know what it meant. (Cheryl, student focus group)

I think at the start I wasn't exactly sure what I was meant to be getting out of it...I knew what I wanted but I wasn't sure exactly what the purpose was of the 
whole set up. So that made it more difficult for us to know. We were completely new to it so it made it a little bit more difficult to know what we were expecting. (Grace, student focus group)

Students' perceived lack of clarity was echoed by mentors and one mentor remarked:

I don't think [students] have any understanding at all of what mentoring is supposed to be about and their responsibility in it. I don't think they understand that. (Mentor 6)

This apparent lack of understanding among some students about what being mentored actually entailed may suggest that some of them had signed up to the programme but were less clear about the demands and expectations that it was going to require of them.

However, some students had a better understanding about what mentoring entailed even though they were in a minority.

Before we got given our mentor we all had to like write what you would like your mentor to provide for you. I put something down like 'help with chemistry or things like that'......so the mentors were all kind of tailored to what we wanted... [A mentor] It's someone that is there to help you with your exams or to be a friend if you can't look up to your teacher.... (Kate, student focus group)

These findings suggest that in addition to the induction for mentors being not well aligned, this was further compounded by a general lack of clarity for the students of what mentoring entailed.

\section{Mentor-mentee matching}

On the programme, it was felt that simply matching a mentor with a mentee on the basis of a similar career interest was an inadequate criterion. Personality was considered to be important in the matching process.

Personality might be quite good because like if someone's shy then they don't really want someone who's like outgoing...like if they're both shy then they get on a bit better... Match them up a bit. (Cheryl, student focus group) 
...maybe a quiet one needs to go with somebody who can draw them out a wee bit to get a kick-start... What is key for me is not the skill set but the personality.... (Mentor 5)

Students appeared to appreciate it when they felt they had been properly matched with a mentor based on personality.

It's sort of weird because we actually sort of had the same traits and personality at times, that was quite weird. (James, student focus group)

As suggested in the literature, some of the criticisms levelled against mentoring stem from a mismatch between mentor and mentee interests, personality and experience (McDowall-Long 2004). The need to consider the personality factor as 'chemistry' between a mentor and mentee is particularly important (Johnson 2002).

\section{Motivation of mentees}

A mentoring relationship appeared to work better where it was a two-way process, with students and mentors both initiating contact as well as prioritising topics for discussion. ... If I don't chase her and ask her what she wants then she won't come to me, whereas when she does have her meetings she knows there are benefits. (Mentor 3)

A mentor expressed frustration at the inability of mentees to take a lead. ... [Adults] know what they want and they will drive sessions, whereas with a student, you have to push them to contact you, which I think is the wrong way around. (Mentor 11)

Some students acknowledged how they were unable to maintain the initial enthusiasm they had for mentoring.

...In the beginning there was partial momentum for us to keep going with it, but then it just sort of...like...trailed off. I would take more of the blame and say that I contacted him less than he contacted me. (Fred, student focus group) 
In some cases this was due to the pace of work in S5 and being preoccupied with the preliminary exams in the earlier stages of building up a relationship.

It was difficult for me to make time for my mentor and the same for her for me. (Grace Student focus group)

Several students expressed the wish that mentoring had begun in the previous school year to enable a longer time for the relationship to develop. Others specifically valued the role of the mentor during their preparation for examinations.

Then like when it comes to like your serious work [S5] and stuff you'll have like a closer relationship. (Cheryl Student focus group)

I saw her about four or five times throughout the year but I saw her a lot more towards the exams because she was helping me with revision and that sort of thing. (Kate student focus group)

Some of the students who needed specific help with academic work from a mentor maintained contact and benefited prior to the main examination period in May. Others met their mentors less and less as they individually prepared for their examination.

\section{Appropriateness of spaces for mentor-mentee meetings}

Most meetings between mentors and their mentees took place on school premises.

While this was expected, accessibility to quiet spaces within some schools was found to be an issue.

I arrived at the school the first time... then eventually a teacher said: 'well, the two of you can go and sit in the corner of the classroom over there'.... (Mentor 4)

Students also acknowledged some degree of complexity in arranging a mentoring meeting in school during school time.

It seemed really restricted at school. (Grace, student focus group) 
However, it must be noted that mentors were aware that a duty of care with regards to student safety placed a particular onus on schools.

...I was conscious that the school were probably also quite nervous about this complete stranger meeting with one of their students... I certainly felt as though they quite sensibly felt a responsibility to that child, and that's why they were probably comfortable putting me in a big classroom which was actually quite public...It meant you could have a decent conversation. (Mentor 4)

So, while meetings in schools were generally viewed as a good thing, another mentor felt that such meetings symbolically created unequal power relations, similar to a teacher-pupil relationship.

...But meeting in the school changes the dynamic between the two people because it automatically puts the adult into an authority role. (Mentor 6)

Equally interruptions and lack of privacy, for example in a school common room, meant that informal public spaces outside the school (e.g. a coffeehouse) were viewed more positively in building a mentoring relationship. Two students and one mentor commented they had additionally held meetings outside of school.

...I thought I quite liked going for a coffee... it's more mature and more informal. (Mentor 5)

Other students indicated a preference for meeting their mentor outside of school as they considered it to be more informal.

Yeah she'd come to the school. I think I would have preferred it if it was outside of school like meeting up at Starbucks or something, a little bit less formal. (Kate, Student focus group)

It's [coffee house] a nice relaxed atmosphere ...especially with sound around you if there's just the two of you [meeting in school] and no one is talking...it can get awkward. (Grace, Student focus group)

These findings show that venues for mentoring sessions may have symbolic significance and therefore require a great deal of consideration. Notwithstanding the 
mentors having undergone DS clearance, there was reluctance on the part of some of the teachers to allow the mentors to meet in private with pupils in school.

\section{Mentee-mentor communication}

In addition to having face to face meetings, which ranged from fortnightly, once a month or more infrequently, communication was maintained through mobile phone (texting and calling) and email. These were viewed as the most effective means of maintaining communication, although not all mentors had their mentee's mobile number and one school required the mentor to communicate with his mentee via a teacher. The communication modes favoured by young people were viewed helpful in building and sustaining the relationship between mentors and students, even though some of these tended to pose different challenges for some of the mentors.

We communicate via email and we sent like a few text messages but it was mainly email. (Kate, student focus group)

Similarly, a mentor noted:

With [my mentee], we text each other a lot, he's like texting by phone but I always go up [to see him] roughly around about once a fortnight. (Mentor 5)

Where there was a considerable geographical distance between one mentor and mentee, then technology such as online video for example, Skype, enabled face to face contact to be maintained. Popular social media such as Facebook appeared to be more popular with females (two mentors and three mentees) citing this mode, compared to it not being mentioned by any male. However, some mentors were initially apprehensive about using Facebook, to develop relationships with mentees. 
I have to say I was reasonably reluctant to accept her as a friend on my

'Facebook' for a period of time. Then I thought, well, actually the relationship isn't really building...I thought well it's a way that I can say I trust you. (Mentor 6)

Apart from the individual mentor's initial reluctance to adopt social media to build a mentoring relationship, there was restriction on the use of such social media between a mentor and mentee in certain work environments.

I wasn't allowed to [Facebook] with my mentor because she works in the college so she is not allowed to add students. (Grace, student focus group)

So, while popular social media offer readily accessible and student-friendly approaches to communicating with mentors, it is also important to bear in mind that there may be some restrictions on how some of these tools are actually utilised. Equally it should not be assumed that all young people feel comfortable with technology as one male student did not possess a mobile phone and emailed his mentor, while for the other two male students, the preferred mode of contact was also via email rather than texting.

\section{Role for schools in mentoring}

Although the six selected secondary schools had all been involved in discussions about the mentoring programme reported here, it was felt that some schools could have taken on a greater role and responsibility in the programme.

...I think [schools] could have done a bit more to make sure that pupils understood what to expect from mentors, and how to get the best out of having a mentor but that wasn't done and I think that's probably why the relationships have varied so much across the whole group of mentors. (Mentor 9)

Another mentor echoed these sentiments by remarking:

I would like to see schools take on a more proactive role in trying to encourage and make mentoring happen ... And no disrespect to them they're busy people, but they've not put any thought into how they are going to bring external nonteaching people from the world of work into the school and how to make that work for their young people. (Mentor 4) 
Some schools were more enthusiastic and gave greater support to the mentoring programme than others. This was partly due to them having greater numbers participating compared with other schools which had only one or two students involved.

\section{Conclusion and implications}

As indicated earlier, our findings mirror many of those already identified in previous mentoring studies albeit in different contexts and for different purposes (Garvey 2006; Kolar and McBride 2011; Roberts 2000). However, what we would like to argue is that our study highlights a number of factors which need to be carefully considered when implementing school-based mentoring involving adults other than teachers. Some of the factors we have highlighted such as mentor-mentee matching, training and motivation are similar to previous findings by other studies (e.g., Johnson 2002; Sims et al. 2000). Socio-motivational mentoring highlights the significance of involvement and structure as key elements of successful mentoring (Larose and Tarabulsy 2005). It is therefore crucial that our study identifies induction, clarity of what mentoring entails, mentormentee matching, appropriateness of meeting spaces, communication, school involvement in addition to mentees' motivation as essential factors in implementing school-based mentoring.

In our study, mentors and the coordinator of the programme felt that the induction needed to be more focussed on young people for this particular programme. It is suggested that it would be helpful if mentors and mentees were much better informed of the purpose that mentoring is supposed to play, and the roles that mentees and mentors are supposed to assume in their respective dyads. Equally, the process of matching mentors and mentees needs to be extended beyond similar career interests to 
also consider personality. For example, the introductory meeting between mentors and mentees could be used to decide whether or not there are personality differences between mentors and mentees. Mentoring between the two parties would then begin only when both are willing to work with each other (Hickman and Garvey 2006). However, it is reassuring that there were no identified general personality clashes within the dyads on the programme.

With regards to motivation by students on the programme, Larose et al. (2009) also found that mentee motivation is an essential prerequisite for effective mentoring. Diminished motivation could be partly due to several reasons such as pressure of school work, impending examinations whereby students used most of their 'free' time to study independently, or a career change thereby viewing the mentor as not a proper match with their new career intentions.

Importantly, there were clearly issues about the nature and means of communication between students and adults on school-based mentoring. It is clear that social media provided a great deal of flexibility for students and adults to arrange meetings as well as have virtual meetings. In the current era of rapid technological growth and high affinity with technology by young people, the contribution of technology and social media in mentoring should be harnessed as it is generally popular among students. However, this also raises the need for safeguards to be in place in such mentoring relationships, both for mentees and mentors. For example, there are also certain restrictions imposed by workplaces, i.e. the college, to the use of social media in certain mentee-mentor dyads and these need to be recognised and alternative channels identified. Specifically and for legal reasons, if mentees are under 16 years, there is a need to follow child protection regulations, and consider gender-based pairings, as well as greater involvement of parents. Further research in this area should be a priority. 
With regards to low proactive involvement by some schools on the programme and the need for appropriate meeting spaces, it is suggested that greater school involvement be encouraged. The role that schools ought to play in such programme is self-evident when one considers the duty of care that teachers have especially where mentees are less than 16 years and also in ensuring that mentor-mentee meetings were of high quality. It could be argued that students on the programme required reassurance on how mentoring was complementary to the role of guidance teachers for it to have been more beneficial. It might be necessary that guidance teachers play a greater role and are integral to school-based mentoring involving adults outwith schools. In addition and based on their role, if teachers are not sufficiently interested or have no time for initiatives such as mentoring, such programmes will definitely not be successful. However it is necessary to acknowledge that the mentoring project reported here was set up quickly within a short time scale in response to the students' request and it is possible that insufficient time was made for dialogue with individual teachers in the early stages.

Interrelated with greater school involvement is the issue of appropriateness of meeting spaces for mentors and mentees. Through such greater involvement, teachers, mentees and mentors may be able to engage in further dialogue to clarify as well as identify and agree on mutually appropriate spaces in which mentor-mentee meetings may take place without any disruption and at the same time, without any undue power imbalance. It is likely that such greater involvement at the outset of the mentoring programme and on-going dialogue would allow schools and mentoring coordinators to formulate appropriate protocols to address some teachers' reluctance to allow 'strangers', who in this case are adults, to talk with students in private in schools. This would subsequently improve trust between teachers and mentors (Clutterbuck 2001). 
Finally, it has been noted that mentoring initiatives of the kind in our study tend to be short-term and single site projects, and therefore have restricted impact. Implementing large-scale and long-term programmes may go a long way in improving many young people's lives (Kolar and McBride 2011). While high achieving students tend to perceive mentoring as an attractive way to consolidate their learning and general life skills, bringing more low achievers to voluntarily agree to participate in schoolbased mentoring may go a long way to improving their overall educational and career prospects (Larose et al. 2009). This was reflected in a comment from a teacher at one of the schools who noted that 'mentoring should be done for the students who aren't so academic and aren't so sure about what they want to do with their life'.

\section{References}

Ahn, J. 2010. "The Role of Social Network Locations in the College Access Mentoring of Urban Youth.” Education and Urban Society 42 (7): 839-859.

Armstrong, D., A. Gosling, J. Weinman, and T. Marteau. 1997. "The Place of InterRater Reliability in Qualitative Research: An Empirical Study."Sociology 31: 597-606.

Authors. 2011. [Author information removed for review process].

Bartlett, S., and D. Burton. 2007. Introduction to Education Studies. London: Sage.

Britner, P., F. E. Balcazar, E. A. Blechman, L. Blin-Pike, and S. Larose. 2006.

"Mentoring Special Youth Populations." Journal of Community Psychology 34 (6): 747-763.

Clutterbuck, D. 2001. Everyone Needs a Mentor. London: Chartered Institute of Personnel Development. 
Colley, H. 2003. “Engagement Mentoring for 'Disaffected' Youth: A New Model of Mentoring for Social Inclusion.” British Educational Research Journal 29 (4): $521-542$.

Colvin, J. W., and M. Ashman. 2010. "Roles, Risks, and Benefits of Peer Mentoring Relationships in Higher Education.” Mentoring and Tutoring: Partnership in Learning 18 (2): 121-134.

Day1.2013. Available at http://www.day1.uk.com/index.htm [accessed online July 2013].

Denzin, N., and Y. Lincoln. 1994. Handbook of Qualitative Research. Thousand Oaks, CA: Sage.

Education Scotland. 2013. Available at http://www.educationscotland.gov.uk/supportinglearners/whatissupport/universa 1support/sharingpractice/tutorprogramme.asp [accessed online July 2013].

Evertson, C., and M. Smithey. 2001. 'Mentoring Effects on Protégé' 'Classroom Practice.” Journal of Educational Research 93 (5) 294-304.

Hall, J. C. 2003. "Mentoring and Young People: A Literature Review." SCRE Research Report. Glasgow: University of Glasgow.

Hickman, G. P., and I. J. Garvey. 2006. “An Analysis of Academic Achievement and School Behaviour Problems as Indices of Program Effectiveness among Adolescents Enrolled in a Youth-Based Mentoring Program.” Journal of At-Risk Issues 12 (1): 1-9.

Hughes, C., E. Boyd, and S. J. Dykstra. 2010. "Evaluation of a University-Based Mentoring Program: Mentors' Perspectives on a Service-Learning Experience.” Mentoring and Tutoring: Partnership in Learning 18 (4) 361-382. 
Johnson, W. B. 2002. “The Intentional Mentor: Strategies and Guidelines for the Practice of Mentoring." Professional Psychology: Research and Practice 33 (1) $88-96$.

Kolar, D. W., and C.A. McBride. 2011. "Mentoring At-Risk Youth in Schools: Can Small Doses Make a Big Change?" Mentoring and Tutoring: Partnership in Learning 19 (2): 125-138.

Langdridge, D. 2004. Introduction to Research Methods and Data Analysis in Psychology. Harlow: Pearson Education.

Lankshear, C., and M. Knobel. 2004. Teacher Research: from Design to Implementation. Maidenhead: Open University Press.

Larose, S. and G. Tarabulsy.2005. “Academically At-Risk Students”. In Handbook of Youth Mentoring, edited by D. L. DuBois, and M.J. Karcher, 440-453. Thousand Oaks, CA: Sage Publications.

Larose, S., D. Cyrenne, O. Garceau, M. Harvey, F. Guay, and C. Deschenes. 2009. “Personal and Social Support Factors Involved in Students' Decision to Participate in Formal Academic Mentoring." Journal of Vocational Behaviour 74 (2009):108-116.

Larose, S., D. Cyrenne, O. Garceau, M. Harvey, F. Guay, F. Godin, and C. Deschênes. 2011. “Academic Mentoring and Dropout Prevention for Students in Math, Science and Technology." Mentoring and Tutoring: Partnership in Learning 19 (4): 419-439.

Leidenfrost, B., B. Strassnig, A. Schabmann, C. Spiel, and C. Carbon. 2011. "Peer Mentoring Styles and Their Contribution to Academic Success among Mentees: a Person-Oriented Study in Higher Education.” Mentoring and Tutoring: Partnership in Learning 19 (3) 347-364. 
Lunsford, L. 2012. "Doctoral Advising or Mentoring? Effects on Student Outcomes." Mentoring and Tutoring: Partnership in Learning 20 (2): 251-270.

MacCallum, J., and S. Beltman.2003. “Bridges and Barriers in Australia's Youth Mentoring Programs" In Global Perspective on Mentoring: Transforming Contexts, Communities, and Cultures, edited by F. Kochan, and J. Pascarelli, 73-103. Greenwich, CT: Information Age Publishing.

MacCallum, J., S. Beltman, and D. Palmer. 2005. "Mentoring as a Context for Developing Motivation. "Paper Presented at Australian Association for Research in Education Conference, Sydney, November 29, 2005.

McDowall-Long, K. 2004. "Mentoring Relationships: Implications for Practitioners and Suggestions for Future Research.” Mentoring and Tutoring: Partnership in Learning 7 (4): 519-534.

Merriam, S.B. 2009. Qualitative Research: A Guide to Design and Implementation. An Francisco, CA: Jossey- Bass.

Miles, M., and M. Huberman. 1994. Qualitative Data Analysis. London: Sage.

Mok, A. T. 2010. "The Effects of Informal Mentoring on Adolescent Development." EdD Dissertation. University of Sydney.

Moore, G. W., J. R. Slate, S. L. Edmonson, J.P. Combs, R. Bustamante, and A. Onwuegbuzie. 2010. "High School Students and Their Lack of Preparedness for College: A State-Wide Study.” Education and Urban Society 42 (7): 817-838.

Philip, K. 2003. "Youth Mentoring: The American Dream Comes to the UK?" British Journal of Guidance and Counselling 31 (1): 101-112.

Reid, K. 2002. "Mentoring with Disaffected Pupils." Mentoring and Tutoring: Partnership in Learning10 (2): 153-169. 
Roberts, A. 2000. "Mentoring Revisited: A Phenomenological Reading of the Literature." Mentoring and Tutoring: Partnership in Learning 8 (2): 145-170. Sandford, R. A., K. M. Armour, and D. J. Stanton. 2010. "Volunteer Mentors as Informal Educators in a Youth Physical Activity Program.” Mentoring and Tutoring: Partnership in Learning 18 (2): 135-153.

Scottish Business in the Community. 2013. Available at http://www.sbcscot.com/programmes/climate-change/environmentalprojects/schools-mentoring/schools-mentoring [accessed online July 2013]

Scottish Executive. 2004. A Curriculum for Excellence: The Curriculum Review Group. Edinburgh: Scottish Executive.

Scottish Executive. 2006. More Choices, More Chances: A Strategy to Reduce The Proportion of Young People Not in Education, Employment or Training in Scotland. Edinburgh: Scottish Government.

Scottish Government. 2008. Curriculum for Excellence: Building the Curriculum 3 -A Framework for Learning and Teaching. Edinburgh: Scottish Government. Scottish Government. 2009. Curriculum for Excellence: Senior Phase Management Board. Discussion paper. Edinburgh: Scottish Government.

Scottish Government. 2010. 16+ Learning Choices, Policy and Practice Framework. Edinburgh: Scottish Government.

Silverman, D. 2005. Doing Qualitative Research. London: Sage.

Sims, D., J. Jamison, S. Golden, and A. Lines. 2000. Running a Mentoring Programme: Key Considerations. Slough: NFER.

Sims, D. 2002. "Mentoring Young People: Benefits and Considerations.” NFER Direct, Spring Issue. 